Sebastian Tabol* (D) https://orcid.org/0000-0002-7348-2173

Wyższa Szkoła Humanistyczno-Ekonomiczna w Brzegu

e-mail: seba.tabol@gmail.com

https://doi.org/10.25312/2083-2923.19/2021_09st

\title{
Tomaš Garrigue Masaryk a herbartyzm
}

\begin{abstract}
Streszczenie: Tomaš Garrigue Masaryk to wybitna postać w historii Czech, był profesorem filozofii oraz politykiem, prezydentem Czechosłowacji. Choć zmarł ponad 80 lat temu, jego dorobek naukowy jest analizowany pod kątem filozoficznym, politologicznym oraz socjologicznym. Niniejszy tekst odpowiada na pytanie, które także pojawia się wśród czeskich filozofów - czy Masaryk jako filozof był zwolennikiem, naśladowcą filozofii Jana Fryderyka Herbarta? Choć w niektórych swoich publikacjach Masaryk powoływał się na prace zwolenników Herbarta, jednak nie świadczy to o tym, iż był herbartystą. Jeśli wspominał filozofię Herbarta, to zawsze po to, aby uświadomić czytelnikom, iż nie zgadza się z jego poglądami, co jasno podkreślał.
\end{abstract}

Słowa kluczowe: Tomaš Garrigue Masaryk, Jan Fryderyk Herbart, Czechy, herbartyzm, filozofia

\section{Wstęp}

Kiedy piszę te słowa, Tomaš Garrigue Masaryk (1850-1937) nie żyje od 84 lat, a mimo to zainteresowanie tą postacią nie maleje. Jest przykładem człowieka, który w nauce i polityce osiągnął wszystko, a trzeba pamiętać, iż przyszedł na świat w ubogiej wiejskiej rodzinie. Uważam, że tak duży dystans czasowy pozwala dokładniej zrozumieć jego idee i dokonania. Nie sądzę, aby myśl Masaryka została szybko przeniesiona do archiwum ${ }^{1}$. Ponadto jest jedną $\mathrm{z}$ najznamienitszych postaci w historii Czech obok

* Sebastian Taboł - doktor językoznawstwa i pedagogiki, pracownik Wyższej Szkoły Ekonomiczno-Humanistycznej w Brzegu, nauczyciel języka polskiego Zespołu Szkół Ekonomicznych w Opolu oraz Publicznego Liceum Ogólnokształcącego z Oddziałami Dwujęzycznymi w Opolu. Jego zainteresowania naukowe koncentrują się wokół polskiej i czeskiej filozofii wychowania oraz relacji polsko-czeskich w zakresie pedagogiki i filozofii. Opublikował następujące prace: Cywilizacja. Refleksje humanisty (Józefów 2013), Edukacja regionalna w szkole średniej (Poznań 2014), Istota czytania (Kraków 2005).

${ }^{1}$ M. Machovec, Tomaš G. Masaryk, Wydawnictwo Melantrich, Praha 1968, s. 15. 
Jana Husa (1370-1415), Jana Amosa Komeńskiego (1592-1670) i Jana Patočki (19071977). Mimo upływu lat jego myśl filozoficzna nie staje się anachroniczna. Jest to także postać, którą wielu Czechów nadal darzy wielkim szacunkiem. Swoje życie podporządkował filozofii, ale zawsze starał się, aby swoje postępowanie dostosować do jej treści. Naprzeciwko Hradczan wiszą nadal trzy fotografie Masaryka, na których są napisane najważniejsze sentencje Tomaša Masaryka, które brzmią: „Nie kradnij, nie kłam, nie bój się”. Filozofię, którą uprawiał, zawsze starał się dostosować do sytuacji geopolitycznej Czechów. Jednak najważniejsze dla niego było to, aby być autentycznym, prawdziwym i by deklaracje zawsze były zgodne z postępowaniem.

\section{Dokonania Tomaša Garrigue'a Masaryka}

Wydaje mi się, że Masaryk jest kojarzony przede wszystkim z działalnością polityczną, która zdynamizowała się po pierwszej wojnie światowej. W 1918 roku został pierwszym prezydentem Czechosłowacji. Pamiętać należy, że swoją działalność polityczną łączył z etycznym, moralnym postępowaniem. Masaryk z polityki uczynił kwestię moralności i służby ${ }^{2}$. Służyć narodowi oraz być przy tym człowiekiem moralnym - to była naczelna jego zasada. Nie znosił kłamców i złodziei. Należy pamiętać, że Masaryk był filozofem, który Czechów zapoznał z angielską i francuską filozofią. Był także pierwszym myślicielem czeskim, który przestrzegał Europę przed marksizmem.

Masaryk w czeskiej kulturze i nauce jest postacią bardzo dobrze znaną i cenioną. Był wielkim mężem stanu, który uczestniczył w wielu wydarzeniach politycznych. Brał aktywny udział w odzyskaniu przez Czechów i Słowaków niepodległości. Traktowany jest jako ojciec niepodległej Czechosłowacji, której poświęcił swoje zdolności i czas. Za jego prezydentury krajem nie targały żadne wstrząsy polityczne. Czechom i Słowakom pod jego rządami żyło się dobrze. Był człowiekiem skromnym i autentycznym, nigdy nie wyrzekł się własnych korzeni, choć budowanie swojej tożsamości nie przychodziło mu łatwo. Życzyłbym wielu politykom takiego zaufania i atencji, jaką miał ten człowiek. Był prezydentem Czechosłowacji przez prawie 4 kadencje. Jego spuścizna intelektualna jest bogata i różnorodna. Jego naukowa pasja była ukierunkowana przede wszystkim na filozofię i dlatego moja naukowa uwaga zostanie skierowana na jego dorobek filozoficzny w powiązaniu z herbartyzmem.

Filozofia Masaryka była skoncentrowana przede wszystkim na człowieku i jego naturze. Analizował czeską myśl narodową. Brał aktywny udział w intelektualnej dyskusji na temat sensu dziejów czeskiego narodu, z którym czuł się mocno związany. Na jego myślenie filozoficzne wpływ mieli przede wszystkim: Platon, David Hume, August Comte, Franz Brentano, John Stuart Mill oraz Herbert Spencer. Starał się, aby filozofia, którą uprawiał, nie była oderwana od rzeczywistości, lecz pomagała żyć.

2 M. Bankowicz, Koncepcja demokracji i niepolitycznej polityki Tomasza Garrigue’a Masaryka, „Prace Komisji Środkowoeuropejskiej PAU”, 2015, t. XXIII, s. 29. 
Całą swoją refleksję filozoficzną podporządkował prawom moralnym. Jego filozofię określano jako „filozofię praktyki”", „filozofię ludzkiej egzystencji”4 oraz „filozofię ludzkiego dzieła" ". Krytykował wszelką filozofię spekulatywną, która lekceważyła wolność człowieka, refleksję etyczną oraz codzienność. Nie znosił w uprawianiu filozofii także dogmatyzmu oraz abstrakcji intelektualnej.

W Polsce osoba ta cieszy się zainteresowaniem naukowców wielu dyscyplin: politologii, prawa, socjologii, filozofii oraz historii, co można dostrzec po artykułach oraz monografiach, które były publikowane w ostatnim dziesięcioleciu6.

Jego filozofia jest całkowicie zorientowana na człowieka. Jednak jednym z elementów jego filozofii na pewno nie jest herbartyzm, i to stanowisko pragnę w tym opracowaniu w formie artykułu przedstawić.

\section{Herbart i zarys jego filozofii}

Nim zastanowimy się, czy Masaryk był zwolennikiem filozofii Herbarta i jego wiernym naśladowcą, pragnę, aby wcześniej zapoznać się z zarysem twórczości filozoficzno-pedagogicznej Herbarta. Myśl Johanna Herbarta ukształtowała mentalnie Europę. Jego dokonania są do dziś analizowane między innymi przez naukowców czeskich. Jego dorobek jest bardzo bogaty, co może mieć związek z tym, iż dokonania Herbarta nie zostały przez czeskich filozofów i pedagogów gruntownie i dokładnie zbadane. Dorobek Oldenburczyka dotyka praktycznie całej humanistyki ${ }^{7}$. Jednak czescy naukowcy skoncentrowali swoją uwagę przede wszystkim na filozoficznych aspektach twórczości Herbarta. Choć jego dokonania przetrwały do naszych czasów, to dzisiaj nikt z czeskich filozofów i pedagogów nie analizuje jego dorobku. Pokolenie czeskich filozofów, które pojawiło się po śmierci Herbarta, starało się jego dorobek ubogacić analizami czynionymi na gruncie psychologii, pedagogiki, filozofii, estetyki.

${ }^{3}$ K. Krofta, Duchovní vi̊dce svého národa, [w:] T.G. Masaryk. hlava státu Československého a duchovní vůdce svého národa, Na pamět čtvrté volby T.G. Masaryka presidentem Československé republiky dne 24. května 1934, Wydawnictwo Otakata Zahradníka, Praha 1934, s. 24.

${ }^{4}$ M. Machovec, Tomaš G. Masaryk..., dz. cyt., s. 58.

${ }^{5}$ J. Srovnal, Masarykova filosofie demkracie a její aktuální principy, [w:] Masarykưv sborník XI-XII 1999-2003, Wydawnictwo Masarykův ústav AV ČR, Praha 2004, s. 38.

${ }^{6}$ Chciałbym w tym miejscu przytoczyć tylko niektóre polskie prace poświęcone dorobkowi tego wielkiego myśliciela. Oto one: M. Bankowicz, Demokracja wedtug T.G. Masaryka, Kraków 2015; P. Eberhardt, Poglady geopolityczne Tomasza Masaryka, „Przegląd Geograficzny” 2017, nr 2; J. Kilias, Narodowość jako problem naukowy. Naród w socjologii czeskiej okresu międzywojennego, Warszawa 2000; A. Łuszczyński, Myśl polityczno-prawna Tomasza G. Masaryka jako rodzaj mitu państwotwórczego, Rzeszów 2013; A. Łuszczyński, Wolność w myśleniu Tomasza G. Masaryka, „Annales Universitatis Mariae Curie-Skłodowska Lublin-Polonia" 2019, nr 1.

7 D. Stępkowski, Trudności i perspektywy współczesnych badań nad Herbartem (na marginesie monografii Andrzeja Murzyna: J.F. Herbart i jego miejsce w kontekście pokantowskiej myśli idealistycznej), „Przegląd Pedagogiczny” 2088, nr 2, s. 26. 
Zdaniem Herbarta między pedagogiką a filozofią występuje szczególny związek. Dla tego myśliciela obie dyscypliny powinny ze sobą współpracować, a nie rywalizować. Ich wspólnym zadaniem powinno być określenie moralności przyczyniające się do wychowania człowieka. Jest uważany za człowieka, który przyczynił się do naukowej samodzielności pedagogiki. Herbart pedagogikę traktował jako filozofię stosowaną ${ }^{8}$. Innymi słowy zadaniem wychowania człowieka powinno być ukształtowanie jego moralności.

Herbart wniósł wielki wkład w wychowanie człowieka. Swoje metody i programy opracował dla szkół średnich. Był teoretykiem oraz praktykiem. Zajmował się kształceniem chłopców ze sfer mieszczańskich i ziemiańskich. Zależało mu na tym, aby każdy uczeń otrzymał wykształcenie odpowiadające jego zdolnościom. Jest autorem nowatorskiej koncepcji określanej mianem nauczania wychowującego, która stała się centralną ideą jego teorii pedagogicznej. Idea ta polega na odróżnianiu nauczania od wychowania. Ponadto nauczanie podporządkował procesowi wychowania. Jego dokonania były rewolucyjne. Wielu pedagogów uważa go za twórcę naukowej pedagogiki ${ }^{9}$. Należy także pamiętać, że myśliciel ten po śmierci Immanuela Kanta objął po nim katedrę filozofii w Królewcu. Niestety za życia nie doczekał się aprobaty swoich idei, choć miał wielu naśladujących go uczniów. Sława przyszła po jego śmierci. Jego koncepcje cieszyły się ogromnym zainteresowaniem wielu ośrodków naukowych w Europie, w tym Uniwersytetu Praskiego. Zaczęto zakładać towarzystwa, wydawać publikacje, które popularyzowały pedagogikę i filozofię Herbarta. Natomiast uczniowie Herbarta zdobywali katedry uniwersyteckie w wielu ważnych ośrodkach uniwersyteckich, między innymi Willmann na Uniwersytecie Praskim.

\section{Herbartyzm jako nurt filozoficzny w Czechach}

Czeskie myślenie filozoficzne naśladowało rozwój filozofii europejskiej z pewnym opóźnieniem. Zdaniem Miloša Matùška filozofia Hegla w Czechach została zastąpiona filozofią Herbarta. Herbart i jego myśl zaczęła zyskiwać na znaczeniu na terenach korony św. Wacława w latach trzydziestych XIX wieku. Herbart ze swoją filozofią przyjął się w Czechach dlatego, że nie występował konflikt między Herbartem a duchowością czeską. Z drugiej strony może dziwić fakt, że czescy filozofowie niespecjalnie darzyli uwagą metafizykę, ale większość filozofów z tego terenu koncentrowała się na estetyce, pedagogice, psychologii, co było także w centrum zainteresowań Herbar-

${ }^{8}$ D. Stępkowski, Między pedagogika a filozofią Herbarta, „Roczniki Nauk Społecznych” 2008, nr 2, s. 89.

${ }^{9}$ N. Hilgenheger, Johann Friedrich Herbart (1776-1841), „Kwartalnik Pedagogiczny” 1999, nr 3-4, s. 5. 
$\mathrm{ta}^{10}$. Czechom w XIX wieku herbartyzm jawił się jako nowoczesna myśl filozoficzna, którą z wielką chęcią rozwijali na swoim terenie.

Czasy, w których przyszło Masarykowi pracować naukowo, to lata siedemdziesiąte XIX wieku aż do lat trzydziestych XX wieku. W czeskiej filozofii, która powstawała w tym czasie, można w niej wyszczególnić następujące etapy: herbartyzm (lata pięćdziesiąte do lat dziewięćdziesiątych XIX wieku), pozytywizm (od siedemdziesiątych do osiemdziesiątych lat XIX wieku) oraz neotomizm (od początku lat osiemdziesiątych XIX wieku). Sam herbartyzm swój rozkwit na ziemiach czeskich miał w latach $1865-1885^{11}$.

Czeski herbartyzm miał charakter nieco liberalny, kładł nacisk przede wszystkim na racjonalizm, naukową trzeźwość, dokładność oraz szacunek dla faktów. Są to także cechy czeskiego myślenia filozoficznego, które zawsze przejawiało nowoczesne podejście w reagowaniu na najnowsze poglądy filozoficzne. Jednak czescy protagoniści Herbarta, działający po śmierci niemieckiego myśliciela, starali się je modyfikować na gruncie psychologii, pedagogiki, estetyki. Wskazuje na to obszerna praca Ivo Tretery pt. Herbart a jeho stoupenci na pražské univerzitěr ${ }^{12}$.

Zdaniem Ivo Tretery herbartyzm przeniósł się z Niemiec do Cesarstwa Austriackiego, a stamtąd do Czech. Kluczową rolę w szerzeniu myśli Herbarta w Cesarstwie odegrał Leopold Rembold mający szerokie znajomości na Uniwersytecie Wiedeńskim, z którym współpracował. To z tego ośrodka akademickiego promieniała myśl Herbarta na teren Czech. Z Wiednia do Pragi herbartyzm przeniósł się dzięki Františkowi Exnerowi, który uczestniczył w wykładach Rembolda. Po nich Exner stał się w całej pełni zwolennikiem i propagatorem herbartyzmu w Czechach. Exner stał się pierwszym herbartowcem ${ }^{13}$. Rembold założył szkołę myśli Herbarta w cesarstwie Habsburgów. Drugim, którego można nazwać uczniem Rembolda, był Johann Ritter von Lichtenfels. W latach 1826-1831 pracował na Uniwersytecie Karola, na którym zaznajamiał studentów z herbartyzmem, jednak nie z takim zaangażowaniem, jak to czynił Exner ${ }^{14}$. Sam Exner wychował swoich następców w osobach Františka Cupra, Gustava Adolfa Lindnera, Augustina Smetany oraz Roberta Zimmermanna.

Z początkiem lat pięćdziesiątych XIX wieku herbartyzm zaczął na dobre osadzać się w filozofii czeskiej. Wyparł idealizm oraz heglizm. Analizując rozwój myśli Herbarta na terenie Czech, można zauważyć, że wśród zwolenników tego nurtu występują Czesi i Niemcy. Pierwszym niemieckim filozofem, który przybliżył oraz rozszerzył rozumienie herbartyzmu, był František Exner (1802-1853), profesor

${ }^{10}$ M. Matùšek, Patř́ Miroslav Tyrš k herbartovské estetické škole?, „Filosofický časopis” 2013, nr 5, s. 672 .

${ }^{11} \mathrm{~J}$. Zumr, Některé otázky českého herbartismu, [w:] J. Popelová-Otáhalová, K. Kosík (red.), Filozofie v dějinach českého národa, Wydawnictwo Československé Akademie Věd, Praha 1958, s. 174.

12 I. Tretera, Herbart a jeho stoupenci na pražské univerzitě, Wydawnictwo Univerzita Karlova, Praha 1989.

13 Tamże, s. 142 i nast.

14 Tamże, s. 140-142. 
filozofii teoretycznej i moralnej, pracownik naukowy Uniwersytetu Karola w Pradze. W 1825 roku obronił doktorat $\mathrm{z}$ filozofii i przez wiele lat pracował naukowo na Uniwersytecie Wiedeńskim. Od 1827 roku prowadził wykłady z filozofii, a rok z później z pedagogiki. Największą popularnością cieszyły się wykłady z filozofii. W 1832 roku został mianowany profesorem zwyczajnym i po śmierci Johanna Lichtenfelsa, ucznia Leopolda Rembolda, który utwierdzał w Cesarstwie Habsburskim myśl Herbarta, przeniósł się na Uniwersytet Karola w Pradze - choć wolał dostać posadę profesora filozofii na Uniwersytecie w Linzu. Starał się również o podobną posadę na Uniwersytecie w Bonn.

\section{Herbartyzm według Tomaša G. Masaryka}

Należy zauważyć, że dotąd nikt w Polsce nie zajął się problematyką herbartyzmu w filozofii Masaryka. Już na początku analizy jego refleksji filozoficznej, która jest różnorodna i bogata, należ zadać pytanie: Czy myśl filozoficzna Herbarta miała wpływ na refleksję Tomaša Garrigue’a Masaryka? Drugie pytanie, które się nasuwa, jest następujące: Czy Masaryk był zwolennikiem tej filozofii i naśladował ją? Czy naśladował myśl, którą rozwijało pokolenie zwolenników Herbarta, które pojawiło się po śmierci niemieckiego myśliciela?

Uważam, że Masaryk formował swoją myśl filozoficzną w czasach, gdy herbartyzm w Czechach był w pełni rozkwitu. Wśród jego nauczycieli znajdowały się osoby, które naśladowały myśl Herbarta. Takim nauczycielem z pewnością byli Franz Brentano oraz Robert Zimmermann. Masaryk studiował filozofię na Uniwersytecie Karola w Pradze w 1882 roku. Ze zwolennikami filozofii Herbarta miał także styczność na Uniwersytecie w Lipsku, gdzie studiował w latach 1876-1877. Był to wtedy najwybitniejszy ośrodek uniwersytecki, który w centrum swoich zainteresowań naukowych postawił twórczość Jana F. Herbarta. Podczas studiów w tym ośrodku Masaryk miał kontakt z wybitnymi zwolennikami myśli Herbarta: Moritzem Drobischem, Ludwigiem Strümpellem, Tuiskonem Zillerem, Wilhelmem Wundtem. Masaryk Wundta uznawał za kontynuatora psychologii Herbarta. Z niektórymi wymienionymi powyżej osobami Masaryk współpracował później jako naukowiec.

Po powrocie z Lipska do Pragi nawiązał współpracę z Otakarem Hostinským, który był reformatorem estetyki Herbarta. Na Uniwersytecie Karola w Pradze Masaryk miał okazję uczestniczyć w wykładach Gustava Adolfa Lindera, uznanego profesora pedagogiki i psychologii, zwolennika herbartyzmu oraz Josefa Durdíka. Z tym ostatnim Masaryk nie miał dobrych relacji, co później wpłynęło na rozbudowaną między nimi konfrontację naukową. $Z$ tych konfrontacji można wywnioskować negatywne ustosunkowanie się Masaryka do herbartyzmu ${ }^{15}$.

${ }^{15}$ J. Svoboda, Masaryki̊v realismus a filozofie pozitivismus, Wydawnictwo Filosofický ùstav AV ČR, Praha 2017, s. 235. 
Pragnę zwrócić uwagę, iż dokładna analiza dorobku Tomaša Masaryka dokonana przeze mnie wskazuje, że czeski filozof tylko raz powołał się na pracę Roberta Zimmermanna (Geschichte der Aesthetik - 1858) - zwolennika herbartyzmu. Tę cytację znajdziemy w pracy pt. Základové konkretne logiky (Praga 1885) na stronie $110^{16}$. Co się tyczy tej książki, to na stronie 111 znajdujemy taki zapis: „ethikové někteří měli nešt’astný napad, svou vědu podřizovati aesthetice"17. Moim zdaniem właśnie tak estetykę rozumiał Herbart, dla którego etyka jest estetyką, czyli nauką o moralnym odczuwaniu tego, co piękne. W odczuciu Masaryka etyka i estetyka to odrębne nauki. Natomiast w wersji niemieckojęzycznej książki Základové konkretne logiky Geschichte der Aesthetik, opublikowanej w Wiedniu w 1887 roku, Masaryk powołał się na tę samą pracę Zimmermanna, co w przypadku wersji czeskojęzycznej. W wersji niemieckojęzycznej cytacja tej pracy znajduje się na stronie $200^{18}$.

Książką Masaryka poświęconą logice jest Pokus o konkretni logiku ${ }^{19}$, w której filozof powołuje się na pracę zwolennika filozofii Herbarta Wilhelma Volkmanna pt. Lehrbuch der Psychologie, zgadzając się z Volkmannem w kwestii podziału psychologii na konkretną i abstrakcyjną. Masaryk polemizuje jednak dalej z Volkmannem, krytykując go oraz samego Herbarta za przenikanie do psychologii filozofii idealistycznej. W dalszej części pracy Masaryk wytyka Herbartowi błędne myślenie dotyczące psychologii polegające na pojmowaniu tej nauki jako dyscypliny pomocnej w rozwoju matematyki ${ }^{20}$.

W książce Masaryka pt. Sebevražda ${ }^{21}$ można natknąć się na cytowanie dzieła innego zwolennika Herbarta - Moritza Drobischa Die moralische Statistik und die menschliche Willensfreiheit. Cytując tę pozycję, Masaryk zastanawia się nad kwestią samobójstwa, która nie jest kategorią filozofii Herbarta, lecz stawia otwarte pytanie: Jakiemu prawu podlega samobójstwo?

W kolejnej pracy Masaryka pt. Univerzitní přednašky zauważyłem spostrzeżenie czeskiego uczonego, z którego wynika, iż Masaryk nie zgadzał się z Herbartem w kwestii postawienia równości między etyką a estetyką. Zdaniem czeskiego pre-

${ }^{16}$ T.G. Masaryk, Základové konkretne logiky. Trúdění a soustava věd, Wydawnictwo Masarykův ústav AV ČR, Praha 2001, s. 110.

17 „Niektórzy etycy mieli nieszczęśliwy pomysł, aby swoją naukę podporządkować estetyce” tłumaczenie własne S.T.

18 T.G. Masaryk, Versuch einer concreten Logik, Wydawnictwo Verlag von Carl Konegen, Wien 1887, s. 200.

19 T.G. Masaryk, Pokus o konkretni logiku, Wydawnictwo Masarykův ústav AV ČR, Praha 2001, s. $105,153$.

20 Tamże, s. 113.

${ }^{21}$ T.G. Masaryk, Sebevražda hromadným jevem společenským moderní osvěty, Wydawnictwo Laichter, Praha 1904, s. 341. 
zydenta piękno jedynie ukierunkowuje moralność człowieka, ale nie zgadza się on $\mathrm{z}$ twierdzeniem Herbarta, że dobro i piękno można połączyć2 ${ }^{22}$.

Są to jedyne ślady myśli Herbarta w twórczości naukowej Masaryka. W jego dorobku naukowym nie ma tekstów, które rozwijałyby herbartyzm lub się nim zajmowały. Samo cytowanie tekstów zwolenników Herbarta nie dowodzi, iż Masaryk popierał tę myśl. Moim zdaniem dla Masaryka twórczość Herbarta nie stanowiła nurtu, którym by się interesował. Żadnej monografii czy artykułu nie poświęcił prezydent Czechosłowacji Herbartowi. W wyżej wymienionych pracach znajdujemy ślady cytowania prac zwolenników Herbarta, ale nie miały one uświadomić czytelnikom, iż czeski filozof jest Herbartem szczególnie zainteresowany. Masaryk pracował ze zwolennikami Herbarta, ale w pracach czeskiego filozofa są zaledwie ślady powoływania się na myśl Oldenburczyka. Jednak, jak twierdzi Josef Zumr, wcale nie musi to oznaczać, że Masaryk nie rozwijał filozofii Herbarta. Jest to jedyny argument tego autora ${ }^{23}$. Zumr w swojej pracy sam przyznaje, że w publikacjach Masaryka znajdziemy mało dowodów na to, że Masaryk był zwolennikiem Herbarta i rozwijał jego myśl. W wielu miejscach swoich dzieł Masaryk dawał do zrozumienia, że nie zgadza się z filozofią Herbarta. Prace, w których to możemy dostrzec, zostały przeze mnie wymienione wyżej, a chodzi o monografie: Pokus o konkretni logiku, Univerzitní přednašky, Sebevražda, Základové konkretne logiky.

Kwestią związku herbartyzmu z filozofią Masaryka zajmował się, jako pierwszy, czeski filozof Zdeněk Nejedlý, autor czterotomowej pracy poświęconej Masarykowi ${ }^{24}$. Nejedlý w tomie III wykazał, że między herbartyzmem a filozofią Masaryka jest istna przepaść. Nie ma między nimi żadnych stycznych punktów, które wykazałyby, że Masaryk był zwolennikiem herbartyzmu. Powstaje pytanie: Dlaczego Masaryk postanowił nie nawiązywać w swym naukowym dorobku do twórczości Herbarta, nurtu bardzo popularnego w czeskiej myśli filozoficznej drugiej połowy XIX wieku? Według przyszłego prezydenta herbartyzm pod koniec XIX i na początku XX wieku był nurtem, który był już mało nowoczesny, niepłodny i statyczny. Masaryk odrzucał Herbarta, ponieważ uważał, że jego myśl to oficjalna filozofia austriacka, która na uczelniach utrzymywała się tylko dlatego, iż taka była wola państwa. A zadaniem Masaryka było rozbić jego siłę wpływu na umysły ówcześnie żyjących intelektualistów, w tym filozofów ${ }^{25}$.

Masaryk podczas analizowania myśli filozoficznej Herbarta doszedł do wniosku, że jego refleksja jest ahistoryczna oraz zawiera subiektywne sądy. Jedyne, co łączy Masaryka $\mathrm{z}$ herbartyzmem, to odporność na wpływ niemieckiej filozofii idealistycznej. Czeski filozof oraz Herbart opracowali swój system filozoficzny w opozycji do ide-

${ }^{22}$ T.G. Masaryk, Univerzitní přednašky I. Praktická filosofie, Wydawnictwo Ústav TGM a Masarykův ústav a Archiv AV ČR, Praha 2012, s. 249.

${ }^{23} \mathrm{~J}$. Zumr, Mame-li kultury, je naší vlastí Evropa. Herbartismus a česká filosofie, Wydawnictwo Filosofický ùstav AV ČR, Praha 1998, s. 81.

24 Z. Nejedlý, T.G. Masaryk, t. I-IV, Wydawnictwo Melantrich, Praha 1932-1937.

25 Z. Nejedlý, T.G. Masaryk, t. III, Wydawnictwo Melantrich, Praha 1935, s. 313. 
alizmu. Również nauczyciel Masaryka prof. Zimmermann krytykował ów idealizm. Pewne podobieństwa można także dostrzec w poglądach Masaryka do Brentano - innego nauczyciela akademickiego prezydenta. Ponadto Masaryk, podobnie do herbartyzmu, usiłował podnieść rangę filozofii jako nauki ${ }^{26}$.

Wielu filozofów poprzednich epok inspirowało Masaryka. Niestety nie inspirował go Herbart. Filozofami - autorami prac, do których odwoływał się Masaryk, byli: David Hume, Karol Darwin oraz Herbert Spencer. Jednak w swoich pracach poświęconych wymienionym filozofom wydatnie korzystał z opracowań naukowców, którzy byli zwolennikami Herbarta. Tymi myślicielami byli Josef Durdík oraz Gustav Lindner, o których wcześniej wspomniałem. Jednak to nie świadczy, iż prezydent republiki rozwijał herbartyzm lub był nim rzeczywiście zainteresowany.

Masaryk miał także pewne przemyślenia dotyczące psychologii, którą uważał za kluczową naukę humanistyczną. Czeski myśliciel, analizując podział nauk dokonany przez Augusta Comte’a, doszedł do wniosku, że wśród tych nauk powinna się znaleźć także psychologia (inspirowana w Czechach Herbartem), ponieważ podstawowymi prawami psychologicznymi kieruje się społeczeństwo.

Jednak między Masarykiem a Herbartem występuje jedna podstawowa różnica. Masarykowi bardzo zależało na teorii, która będzie miała związek z praktyką. Masaryk był osobą zaangażowaną w podnoszenie znaczenia wiedzy, narodu i ludzkości. Nikt wśród ówcześnie żyjących filozofów nie spostrzegał rzeczywistości w taki sposób, jak Masaryk. Cały swój dorobek naukowy poświęcił zagadnieniom filozofii człowieka, demokracji oraz dziejom czeskiego narodu.

\section{Zakończenie}

W niniejszym opracowaniu, które przybrało postać artykułu, nie sposób wspomnieć o wszystkich dokonaniach filozoficznych Masaryka. Jego filozofia koncentrowała się przede wszystkim na humanizmie i pozytywizmie. Można także doszukiwać się w filozofii czeskiego uczonego wpływów wielu innych filozofów. Jednak mówienie, iż Masaryk był propagatorem filozofii Herbarta lub naukowcem, który chciał dokonać rozwoju tej filozofii, jest nadużyciem. W żadnym opracowaniu poświęconym czeskim zwolennikom Herbarta ${ }^{27}$ nie ma wzmianki, by Masaryk był zwolennikiem Oldenburczyka. A budowanie swojej argumentacji na tym, że kilka razy zdarzyło się, iż Masaryk powołał się na pracę zwolennika Herbarta, nie świadczy, że swoją naukową uwagę czeski filozof ukierunkował na ten nurt. Filozofię Herbarta Masaryk uważał za przeżytek, który nie pasuje do nowej rzeczywistości.

${ }^{26}$ J. Svoboda, dz. cyt., s. 234 i nast.

${ }^{27}$ Mam tu na myśli prace, na które w niniejszym opracowaniu powoływałem się już, a są to: J. Zumr, Mame-li kultury, je naší vlastí Evropa. Herbartismus a česká filosofie oraz I. Tretera, Herbart a jeho stoupenci na pražské univerzitě, Praha 1989. 


\section{Bibliografia}

Bankowicz M., Demokracja według T.G. Masaryka, Wydawnictwo Uniwersytetu Jagiellońskiego, Kraków 2015.

Bankowicz M., Koncepcja demokracji i niepolitycznej polityki Tomasza Garrigue’a Masaryka, „Prace Komisji Środkowoeuropejskiej PAU” 2015, t. XXIII.

Eberhardt P., Poglądy geopolityczne Tomasza Masaryka, „Przegląd Geograficzny” 2017, nr 2.

Hilgenheger N., Johann Friedrich Herbart (1776-1841), „Kwartalnik Pedagogiczny” 1999, nr 3-4.

Kilias J., Narodowość jako problem naukowy. Naród w socjologii czeskiej okresu międzywojennego, Wydawnictwo Naukowe Scholar, Warszawa 2000.

Krofta K., Duchovní vi̊dce svého národa, [w:] T.G. Masaryk, Hlava státu Československého a duchovní vůdce svého národa, Na pamět čtvrté volby T.G. Masaryka presidentem Československé republiky dne 24. května 1934, Wydawnictwo Otakata Zahradníka, Praha 1934.

Łuszczyński A., Myśl polityczno-prawna Tomasza G. Masaryka jako rodzaj mitu państwotwórczego, Wydawnictwo Uniwersytetu Rzeszowskiego, Rzeszów 2013.

Łuszczyński A., Wolność w myśleniu Tomasza G. Masaryka, „Annales Universitatis Mariae Curie-Skłodowska" 2019, nr 1.

Machovec M., Tomaš G. Masaryk, Wydawnictwo Melantrich, Praha 1968.

Masaryk T.G., Pokus o konkretni logiku, Wydawnictwo Masarykův ústav AV ČR, Praha 2001.

Masaryk T.G., Sebevražda hromadným jevem společenským moderní osvěty, Wydawnictwo Laichter, Praha 1904.

Masaryk T.G., Univerzitní přednašky I. Praktická filosofie, Wydawnictwo Ústav TGM a Masarykův ústav a Archiv AV ČR, Praha 2012.

Masaryk T.G., Versuch einer concreten Logik, Wydawnictwo Verlag von Carl Konegen, Wien 1887.

Masaryk T.G., Základové konkretne logiky. Třídění a soustava věd, Wydawnictwo Masarykův ústav AV ČR, Praha 2001.

Matùšek M., Patří Miroslav Tyrš k herbartovské estetické škole?, „Filosofický časopis” 2013, nr 5.

Nejedlý Z., T.G. Masaryk, t. III, Wydawnictwo Melantrich, Praha 1935.

Nejedlý Z., T.G. Masaryk, t. I-IV, Wydawnictwo Melantrich, Praha 1932-1937.

Srovnal J., Masarykova filosofie demkracie a její aktuální principy, [w:] Masarykùv sborník XI-XII 1999-2003, Wydawnictwo Masarykův ústav AV ČR, Praha 2004.

Stępkowski D., Między pedagogiką a filozofią Herbarta, „Roczniki Nauk Społecznych” 2008, nr 2. 
Stępkowski D., Trudności i perspektywy wspótczesnych badań nad Herbartem (na marginesie monografii Andrzeja Murzyna: J.F. Herbart i jego miejsce w kontekście pokantowskiej myśli idealistycznej), „Przegląd Pedagogiczny” 2008, nr 2.

Svoboda J., Masarykuv realismus a filozofie pozitivismus, Wydawnictwo Filosofický ùstav AV ČR, Praha 2017.

Tretera I., Herbart a jeho stoupenci na pražské univerzitě, Wydawnictwo Univerzita Karlova, Praha 1989.

Zumr J., Mame-li kultury, je naší vlastí Evropa. Herbartismus a česká filosofie, Wydawnictwo Filosofický ùstav AV ČR, Praha 1998.

Zumr J., Některé otázky českého herbartismu, [w:] J. Popelová-Otáhalová, K. Kosík (red.), Filozofie v dějinach českého národa, Wydawnictwo Československé Akademie Věd, Praha 1958.

\section{Tomaš Garrigue Masaryk and Herbartism}

Abstract: Tomaš Garrigue Masaryk is an outstanding figure in Czech history; he was a professor of philosophy and politician, president of Czechoslovakia. Although he died over 80 years ago, his academic achievements are analyzed in terms of philosophy, political science and sociology. This article answers a question that also arises among Czech philosophers - whether Masaryk as a philosopher was a supporter of the philosophy of Jan Fryderyk Herbart? Although in some of his publications Masaryk referred to the works of Herbart's supporters, this does not prove that he was a Herbartist. If he mentioned Herbart's philosophy, it was always to make readers aware that he did not agree with his views, which he clearly emphasized.

Keywords: Tomaš Garrigue Masaryk, Jan Fryderyk Herbart, Czech Republic, Herbartism, philosophy

\footnotetext{
About the Author

Sebastian Taboł - PhD in linguistics and pedagogy, employee of the University of Economics and Humanities in Brzeg, teacher of Polish at the Economic School Complex in Opole and the Public Secondary School with Bilingual Branches in Opole. His research interests focus on Polish and Czech philosophy of education and Polish-Czech relations in the field of pedagogy and philosophy. He published the following works: Cywilizacja. Refleksje humanisty (Józefów 2013), Edukacja regionalna w szkole średniej (Poznań 2014), Istota czytania (Kraków 2005).
} 